in contrast to those of the arm, forearm, and shoulder. The thigh bones have a prominent linea aspera, the tibiæ are platycnemic. In more than half the humeri there is a perforation of the olecranon fossa.

Some interesting observations were made on the cultural practices of the Natufians, for which evidence was afforded by the skeletal remains. The two upper incisors of the women were extracted in youth. Evidence for the same practice was found by $\mathrm{Mr}$. Turville-Petre at Kebara, between Shukbah and Carmel. The Natufians also seem to have practised cannibalism. The bones are cut and fractured, the cut and broken surfaces showing that this was done when the bones were in a fresh state. This was at Shukbah only. No evidence of mutilation of the dead was found at Carmel or Kebara.
Evidence of a curious practice was found at Kebara. In the mesolithic deposits were found an assortment of bones which had been burned-not when fresh, but after they had been freed from animal matter by burial or exposure. The bones thus treated, which were collected by Mr. Turville-Petre, represent at least 75 individuals, mostly women. A similar collection had been forwarded to Sir Arthur by Mr. Leonard Woolley, which had been obtained from under the foundations of Ur. Here, too, women's bones preponderated. Further, Miss Caton-Thompson had obtained two skulls (female) from Zimbabwe which had been burned after the flesh had disappeared from the bones. Is this evidence, asks Sir Arthur, of a custom in ancient times of digging up the bones of ancestors and submitting them to the ordeal of fire?

\title{
Recent Archæological Field Work in England
}

$\mathrm{T}^{\mathrm{H}}$ OSE members of the International Congress of Prehistoric and Protohistoric Sciences who elected to join the excursions arranged for the week (Aug. 6-13) immediately following the meeting in London, were fortunate not only in being afforded an opportunity to visit a number of important sites, but also in having demonstrated to them the latest results of this season's work by those who are in charge where excavation is now proceeding.

After dividing into two parties, of which one made its headquarters at Cambridge and the other at Oxford, they rejoined at Salisbury. The Oxford party on the way to Salisbury visited Winchester and Easton Down, near Salisbury. At the latter, they were shown the flint mines discovered from the air by Dr. J. F. S. Stone two years ago, and since excavated by him. The site covers 100 acres, and has a system of $\mathrm{V}$-shaped ditches with deep pits at their convergence, similar to those of Grimes Graves, and containing quantities of half-manufactured implements, antler-picks and shoulder-blade shovels. Within the last few weeks, Dr. Stone has discovered a fresh pit of two courses, each eight feet in depth, with a shallower work nearby, which indicate how the neolithic miner worked.

Among the sites visited from Salisbury by the members of the Congress were the Iron Age fortress on Yarnbury Plateau and the Early Bronze Age site at Windmill Hill, which is being excavated by $\mathrm{Mr}$. Alexander Keiller. At Yarnbury the triple line of fortifications surrounds the largest prehistoric strong- hold in Wiltshire. It is $28 \frac{1}{2}$ acres in extent, with ramparts $25 \mathrm{ft}$. high. Within the triple rampart is a single rampart, or rather its remains, and a ditch. Some surprising results achieved in the excavations of the past two months were described by Mrs. M. E. Cunnington. The inner fortifications are not neolithic, as has been thought, but Iron Age work of a period slightly anterior to the triple line. The area was strewn with Romano-British pottery. A cutting in the interior rampart has revealed the post-holes for a chalk revetment sustained against a wooden wall. In the causeway, the only entrance to the fortress, has been found the most impressive Iron Age ditch so far discovered, a V-shaped excavation $12 \mathrm{ft}$. deep, so acute in angle that it would be impossible for two ranks of attackers to stand on the bottom. In the past few weeks there have also been discovered the guard-house and store-house of the fortress, while above the site of the ditch was the skeleton of a man wearing leather boots with hob-nails and bronze decorative studs.

At Windmill Hill, Mr. Keiller described the results of recent work, which now centres upon the excavation of the outer ditch, some $20 \mathrm{ft}$. wide and 8-9 ft. deep. Mr. Keiller announced that one-third of the site, which is the largest so far to be observed as included in this type of Early Bronze Age camp, is to be placed in trust for a century so that its excavation may be delayed until the results can be interpreted in the light of the fuller information which will then be available for archæologists.

\section{Submarine Gravity Survey in the Bahamas}

$\mathrm{A}^{\mathrm{N}}$ interesting piece of geophysical investigation has just been completed by an expedition carried out jointly by the United States Navy and the Department of Geology, Princeton University, with the co-operation of the United States Coast and Geodetic Survey. The introduction, in 1923, by Dr. Vening Meinesz of the Dutch Geodetic Commission, of a gravity pendulum apparatus capable of operating on a base not absolutely free from disturbing oscillation, led to the use of a submarine for the determination of the force of gravity over sea-beds and oceanbeds. During the next three years, three voyages in Dutch submarines were made by Dr. Vening Meinesz, and in the course of these he added much to the knowledge of the distribution of the force of gravity over the earth's surface.

In 1928 the United States showed an official appreciation of this pioneer work by inviting Dr. Vening
Meinesz to bring his apparatus and carry out a similar investigation in United States waters with the help of a submarine of the U.S. Navy. The cruise was carried out in the autumn of 1928 and covered an area of considerable geological interest in the Caribbean Sea, the Gulf of Mexico, and to the north of Porto Rico. With the land pendulum stations established in that region by the United States Coast and Geodetic Survey, a considerable body of evidence was thus made available for the study of questions of isostatic equilibrium and of tectonic development.

It was a natural consequence that a desire should be expressed by geophysicists for the extension of the investigation to cover the whole of the British West Indies. The consent of the British Government for a submarine of the United States Navy to operate in these waters was obtained, and Dr. Vening Meinesz once more placed his special pendulum apparatus and

No. 3277, VoL. 130] 
his own services at the disposal of the expedition. The moving spirit in this work, and the director of the expedition, was Prof. Richard M. Field, of Princeton University. He has, since 1922, made a special study of the stratigraphy and structural geology of the continental borders of the Atlantic Basin. In the course of this study he has led three expeditions to the Bahamas region. Dr. Bowie, chief of the Geodetic Division of the United States Coast and Geodetic Survey, was also an active supporter of the expedition. An observer, Lieut. J. P. Lushene, from his department, accompanied Prof. Field in the yacht Miami, owned and sailed by Lieut. Hugh Matheson, U.S. Naval Reserve, and made pendulum observations at a number of island stations in the region covered by the submarine party. The U.S. submarine S.48 Lieut.-Commander O. R. Bennehoff, with Dr. Vening Meinesz on board, left Guantanamo, Cuba, on Feb. 7, 1932, being accompanied by the parent ship U.S.S. Chewink, Lieut.-Commander G. A. Miller. In the course of the next two months a cruise of some 4000 miles, in three loops, was made by these vessels, a large number of soundings by the sonic and by the supersonic apparatus were made, and the force of gravity was determined at 53 stations.

This notable expedition was given an international character by appointing advisory committees of prominent persons to deal with the subjects : navigation, geophysics, tectonics, oceanography, sedimentation, marine micro-biology. The Royal Society made a grant of $£ 400$ towards the sinking of a bore-hole on Andros Island, Bahamas. In the capable hands of Prof. Field, Dr. Vening Meinesz, and others, the results of the expedition are likely to yield valuable information, not only as to the history of the region, but also in the sphere of tectonics, or the theory of present-day processes in the more active regions in the earth's crust. Gravity survey at sea has come to stay as a major geophysical research, and it is, happily, likely to figure in the not distant future as an object of co-operation between the Navy and scientific authorities of Great Britain.

\section{Calendar of Geographical Exploration}

Aug. 2I, I72 I.-Easter Island

Jacob Roggeveen sailed from the Texel with three ships. On April 6, 1722, he discovered Easter Island, and described for the first time the remarkable stone figures found on that island. A buccaneer, Edward Davis, was reported to have sighted the island in the previous century, but there is no conclusive evidence that he did so. Several other islands were discovered, though it is difficult to identify them from Roggeveen's description; Raiotea in the Society Group was certainly one of them.

\section{Aug. 23, I683.-A Survey of the Galapagos Islands}

A party of buccaneers, among whom were Dampier and Cowley, sailed for the South Seas. They sighted land which they charted as Pepys Island, but which was probably a headland of the Patagonian coast. They were joined by a second ship under Eaton and visited the Galapagos group, where they made a long stay; Eaton and Cowley drew the first fairly accurate chart of these islands, and Cowley's journal long remained the standard authority on them. The islands were discovered by the Spanish in the sixteenth cen. tury and received their name from the giant turtles which have evolved there. Charles Darwin found valuable data for his " Origin of Species " in the Galapagos, which he visited in the Beagle, a large proportion of the fauna and flora being peculiar to the islands.

$$
\text { No. 3277, VoL. 130] }
$$

\section{Aug. 24, I499.-Coast of Venezuela}

Alonzo de Ojeda discovered the great inland Gulf of Maracaibo, which he called San Bartolomé. Ojeda sailed with four vessels from Cadiz in May 1499 , reached Surinam, and coasted past the mouths of the Essequibo and the Orinoco. Rounding the peninsula of Paraguana, they entered a large gulf where they saw pile dwellings, hence they named the gulf and its coasts Venezuela (Little Venice). They passed through the strait to Maracaibo, and after sailing west to Cabo de la Vela, returned home.

\section{Aug. 24, I897.-Gerlache Strait}

Adrien de Gerlache left Ostend in the Belgica on an antarctic expedition, Roald Amundsen being mate and Arçtowski accompanying it as geologist. Funds were raised mainly through the personal enthusiasm of Gerlache and his companions; the Brussels Geographical Society opened a subscription list and the Belgian Government gave a small grant. Soundings were made of the hitherto uncharted sea between Cape Horn and the South Shetlands. The strait named after Gerlache, between the Palmer Archipelago and the mainland, was discovered and Graham Land was followed to Alexander I. Land. Finally the vessel was frozen in for the winter in $71^{\circ} 30^{\prime} \mathrm{S}$. For the first time, a party of scientific workers wintered in the antarctic night; the sun did not appear from May 15 until July 22. The party suffered severely and one died, but scientific observations were steadily continued. The Belgica brought back a wealth of data and specimens, and the Belgian Government published the results for which the expedition is justly famous.

\section{Societies and Academies}

\section{Dublin}

Royal Dublin Society, June 28.-J. Joly : A suggested mode of radiotherapy when long continued feeble gamma radiation may be desirable. Since all living beings are normally exposed to cosmic radiation, it is conceivable that a comparatively mild increase in the exposure to penetrating radiation might be beneficial in certain diseases. This may be effected by the application of a fabric coated with a radioactive paint prepared by mixing very finely powdered uraninite with acetone containing 10 per cent cellulose acetate. This paint adheres firmly to the surface of the fabric.E. J. Sheehy: Effect of the conditions of storage on the vitamin $D$ potency and on other features of cod liver oil. Storage in transparent bottles, or in tinlined containers, or in partly filled barrels, does not materially reduce the vitamin $\mathrm{D}$ potency. Exposure to light bleaches the oil, whilst exposure to air deepens the colour and increases the rate of production of free fatty acid.-William Hughes: A study of Phoma Lingham (Tode) Tesm., and of the 'dry rot' it causes, particularly in swede turnips. A number of fungi occur on diseased plants which are considered forms of Phoma Lingham, but the one which is exclusively associated with typical dry rot of the roots in Ireland, and is predominant on other organs, is identical with the American cabbage black-leg organism and with Cunningham's Strain II.A from New Zealand. On plants other than swede and turnip, Strain II.B predominated. Strain II.A was the only one which consistently produced dry rot of swedes in the field and laboratory. Strains I.B and II.B (with one exception) failed to do so in the field, while producing a rot in the laboratory. Dry rot may originate from three sources, namely, (1) the seed, (2) from diseased roots of a previous crop which survive in the soil, (3) from similiar roots present in the farmyard manure. 